\title{
Mechanizmy utraty i nabywania intronów spliceosomalnych
}

\section{STRESZCZENIE}

Tntrony to wewnątrzgenowe sekwencje niekodujące. Dawniej były uznawane za „śmieciowy" DNA, jednak obecnie uważa się, że są ważnymi elementami wpływającymi na funkcjonowanie genomu. Udowodniono, że introny zwiększają różnorodność transkryptomu i proteomu, spełniają $w$ komórce role regulatorowe, wpływają na ekspresję genów oraz obróbkę, translację i degradację mRNA. Ze względu na sposób powstawania dzielą się na trzy główne kategorie: spliceosomalne, samowycinające się oraz introny tRNA. Introny spliceosomalne są charakterystyczne dla organizmów eukariotycznych. Analizy sekwencji genów ortologicznych w rożnych grupach eukariontów pozwoliły zidentyfikować wiele przypadków nabywania oraz utraty intronów. Niektóre z tych zdarzeń miały miejsce $w$ dalekiej przeszłości, do innych doszło stosunkowo niedawno. Uważa się, że procesy te mogą działać jako jedna z sił napędowych w ewolucji genów eukariotycznych.

\section{WPROWADZENIE}

Introny to „wtrącone” sekwencje nukleotydowe (ang. intervening sequences), usuwane podczas dojrzewania pre-RNA [1]. Występują powszechnie $\mathrm{w}$ jądrowych oraz organellarnych genach eukariontów. Rzadziej spotyka się je u organizmów prokariotycznych - bakterii i archeonów. Sporadycznie ich obecność stwierdza się także u wirusów [2]. Przez wiele lat introny uważano jedynie za „śmieciowy” DNA, tymczasem mogą one odgrywać różne role. Uczestniczą $\mathrm{w}$ regulacji ekspresji genów oraz $\mathrm{w}$ alternatywnym składaniu eksonów, przyczyniając się do zwiększenia różnorodności transkryptomu i proteomu [3]. Niektóre introny kodują małe jądrowe cząsteczki RNA (snRNA) oraz mikro RNA (miRNA) [4]. Introny mogą również być zaangażowane w odpowiedź na czynniki zewnętrzne (stres) [5]. Ponadto obecność intronów wpływa na transport przez błony jądra komórkowego, translację, degradację wadliwego mRNA, a nawet na częstotliwość crossing-over. $\mathrm{W}$ obszarach chromosomów bogatych $\mathrm{w}$ krótkie introny rekombinacja zachodzi częściej niż w regionach z długimi intronami lub pozbawionych intronów [6].

\section{TYPY INTRONÓW U EUKARYA}

Ze względu na sposób wycinania, można wyodrębnić trzy główne rodzaje intronów: (I) introny spliceosomalne [7], (II) introny samowycinające się grupy I [8], II [9] i III [10], oraz (III) introny tRNA [11]. Istnieją też nietypowe introny, których nie sposób zaklasyfikować do żadnej z powyższych kategorii [12].

\section{INTRONY SPLICEOSOMALNE}

Introny spliceosomalne znajdują się w genach jądrowych Eukarya. Posiadają konserwowane ewolucyjnie granice. Najczęściej na końcu donorowym 5' znajdują się nukleotydy GT (rzadziej GC), natomiast na końcu akceptorowym $3^{\prime}$ - nukleotydy AG. Istnieją również introny spliceosomalne o innych złączach, AT na końcu 5' oraz AC na końcu 3' [7]. Usuwanie intronów spliceosomalnych zachodzi przy udziale spliceosomu, czyli złożonego kompleksu małych RNA i białek [13]. Istnieją dwa rodzaje spliceosomu. Podstawowy spliceosom (typu U2, ang. major spliceosome) rozpoznaje introny o granicach GT/C-AG. Składa się z pięciu małych jądrowych RNA (snRNA), oznaczanych jako U1, U2, U4, U5 i U6, oraz wielu specyficznych czynników białkowych. Alternatywny, "mały” spliceosom (typu U12; ang. minor spliceosome) identyfikuje introny o złączach AT-AC (także niektóre ze złączami GT-AG). Ten rodzaj spliceosomu zawiera U11, U12, U4atac, U5 i U6atac snRNA i białka [14]. Introny spliceosomalne są wycinane w wyniku dwóch następujących po sobie transestryfikacji [14]. W pierwszej reakcji zachodzi atak grupy 2 '-OH w nukleotydzie adenozynowym, leżącym w punkcie rozgałęzienia w obrębie intronu, na ostatni nukleotyd końca 5' intronu. Wsku-

\section{lic. Antonina Ignatenko,} mgr Natalia Gumińska,

\section{dr hab. Rafał Milanowski ${ }^{\natural}$}

Zakład Filogenetyki Molekularnej i Ewolucji, Instytut Botaniki, Wydział Biologii, Centrum Nauk Biologiczno-Chemicznych, Uniwersytet Warszawski

https://doi.org/10.18388/pb.2019_292

$\square_{\text {autor korespondujący: milan@biol.uw.edu.pl }}$

Słowa kluczowe: introny, introny spliceosomalne, utrata intronu, nabycie intronu

Podziękowania: Praca powstała podczas realizacji projektu badawczego 2015/19/B/ NZ8/00166 finansowanego przez Narodowe Centrum Nauki. 
tek tego intron przyjmuje postać lassa (ang. lariat)[13]. W trakcie drugiej transestryfikacji grupa 3'-OH z końca odciętego eksonu poprzedzającego intron atakuje wiązanie fosfodiestrowe między ostatnim nukleotydem intronu, a pierwszym nukleotydem kolejnego eksonu. Prowadzi to do uwolnienia intronu oraz ligacji eksonów [4].

\section{INTRONY SAMOWYCINAJĄCE SIĘ}

Introny samowycinające się to rybozymy, które przyjmują stabilną, konserwowaną strukturę drugo- i trzeciorzędową, umożliwiającą ich autokatalityczne wycięcie z pre-RNA bez udziału dodatkowych czynników enzymatycznych. Niemniej w warunkach fizjologicznych ten proces jest często wspomagany przez białka [15]. Introny samowycinające się zostały podzielone na trzy grupy.

Introny grupy I występują u wirusów, bakterii [16], archeonów [17], w organellach półautonomicznych [18] oraz $w$ genach jądrowych rRNA eukariontów [19]. W obrębie intronów grupy I wyróżnia się dziewięć głównych regionów P1-P9. Obszary te tworzą trzy domeny: katalityczną (P3, P7, P8, P9), substratową (P1, P2) oraz szkieletową (P4, P5, P6)[8]. Wycinanie intronów grupy I również odbywa się w wyniku podwójnej transestryfikacji [20]. Pierwszą reakcję zapoczątkowuje atak grupy 3'-OH guanozyny - leżącej w obrębie intronu lub będącej swobodnym kofaktorem - na wiązanie fosfodiestrowe w miejscu splicingowym 5'. Podczas drugiej reakcji, uwolniona grupa 3'-OH odciętego eksonu atakuje miejsce splicingowe 3' [21]. Prowadzi to do ligacji eksonów oraz wycięcia intronu.

Introny grupy II to elementy genetyczne spotykane $\mathrm{w}$ genomach archeonów, bakterii i organelli półautonomicznych [22]. Przyjmują strukturę drugorzędową, składającą się z sześciu domen (D1-D6), które zbliżającą do siebie miejsca cięcia i rozgałęzienia [23]. Introny grupy drugiej posiadają konserwowane ewolucyjnie sekwencje złączy (5'-GUGYG oraz AY-3'), które przypominają motywy występujące $\mathrm{w}$ intronach spliceosomalnych. Introny grupy II też są wycinane w wyniku dwóch transestryfikacji. W pierwszej reakcji następuje atak grupy 2 '-OH wewnętrznej adenozyny na miejsce splicingowe $5^{\prime}$ intronu. W ten sposób tworzy się struktura lassa. W drugiej transestryfikacji, grupa 3'-OH z wolnego końca eksonu poprzedzającego intron atakuje miejsce splicingowe $3^{\prime}$, co powoduje połączenie eksonów i wycięcie intronu [24].

Introny grupy III znaleziono $\mathrm{w}$ genomach chloroplastowych euglenin [25]. Występują zwykle w genach zaangażowanych w transkrypcję i translację. Introny grupy III są zbliżone budową do intronów grupy II, od których zapewne pochodzą [26]. Natomiast są od tych ostatnich krótsze i bogatsze w nukleotydy A i T. W intronach grupy III nie występują domeny II-V. Co więcej, wycięcie intronów grupy III zachodzi w podobny sposób, jak intronów grupy II. W wyniku podwójnej transestryfikacji intron przyjmuje formę lassa, a następnie zostaje usunięty [25]. Introny te wraz z intronami grupy II mogą tworzyć bardziej skomplikowane, piętrowe struktury, nazywane twintronami [27].

\section{INTRONY tRNA}

Introny tRNA są sekwencjami spotykanymi w cząsteczkach pre-tRNA eukariontów oraz mRNA, rRNA, i tRNA archeonów [4]. Pre-tRNA zawierający intron przyjmuje drugorzędową strukturę przypominającą kształtem liść koniczyny. W obrębie cząsteczki pre-tRNA intron znajduje się w odległości jednego nukleotydu od pętli antykodonowej. U Eukarya występuje charakterystyczne wybrzuszenie w miejscu cięcia 3' [28]. Natomiast u Archaea w miejscu cięcia znajduje się konserwowany motyw wybrzuszenie-helisa-wybrzuszenie (ang. bulge-helix-bulge; BHB) [29]. Wycinanie intronów tRNA jest procesem wieloetapowym, w którym biorą udział enzymy: endonukleaza, rozpoznająca wybrzuszenie obok miejsca 3' lub motyw BHB, ligazy RNA oraz fosfotransferazy [30].

\section{NIETYPOWE INTRONY}

U Eukarya występują także introny, których nie można zaklasyfikować do żadnej z przywołanych kategorii. Do takich nietypowych elementów genetycznych należą introny niekonwencjonalne, unikalne dla dwóch grup w obrębie Euglenozoa: euglenin [12] i diplonemidów [31]. Introny niekonwencjonalne nie posiadają konserwowanych sekwencji złączy typowych dla intronów spliceosomalnych (GT/C-AG lub AT-AC), a mechanizm ich wycinania nie został dotąd poznany. Co więcej, introny niekonwencjonalne strukturalnie nie przypominają intronów samowycinających się. W intronach niekonwencjonalnych konserwowane ewolucyjnie nukleotydy znajdują się w pozycjach $+4,5,6$ przy końcu 5' oraz komplementarne do nich nukleotydy, zajmujące pozycje -8, 7, 6 na końcu 3' [12]. Zaobserwowano również, że sekwencje na złączach ekson-intron-ekson spełniają kilka reguł: ostatnimi nukleotydami końca 3' eksonu poprzedzającego intron oraz końca 3' intronu zwykle są pirymidyny (C lub $\mathrm{T})$, pierwsze nukleotydy końców 5' intronu i następującego po nim eksonu to zazwyczaj puryny (G lub A). Natomiast $w$ trzeciej pozycji w eksonie 5' przeważnie leży cytozyna (5'-Y|R, Y|RNC-3') [12,32,33]. Przypuszcza się, że introny niekonwencjonalne wyewoluowały z niewielkich transpozonów - MITEs (ang. Miniature Inverted-repeat Transposable Elements) [12].

\section{POCHODZENIE INTRONÓW SPLICEOSOMALNYCH}

Pochodzenie intronów spliceosomalnych jest dyskusyjne. Nie można jednoznacznie stwierdzić, w jaki sposób doszło do pojawienia się i nagromadzenia tych elementów w genomach [34]. Najbardziej wiarygodnym poglądem, tłumaczącym pochodzenie intronów spliceosomalnych, jest teoria „wielu intronów we wczesnej ewolucji eukariontów" [7]. Scenariusz ten zakłada równoległe nabywanie i utratę intronów. Badania genomów Eukarya umożliwiły odkrycie sekwencji intronów spliceosomalnych w genach ortologicznych $\mathrm{u}$ odległych ewolucyjnie grup. Introny te były obecne $\mathrm{u}$ ostatniego wspólnego przodka eukariontów - LECA (ang. Last Eukaryotic Common Ancestor) [1]. Organizm ten posiadał już mitochondria, które zostały nabyte przez przodka LECA w wyniku endosymbiozy z a-proteobakterią. Genom mitochondrialny LECA najprawdopodobniej zawierał też samowycina- 
jące się introny grupy II [35]. W toku ewolucji przodka LECA mógł nastąpić transfer intronów organellarnych do genomu gospodarza, a następnie ich rozprzestrzenienie się [36]. Za wystąpienie tego zjawiska mogło odpowiadać wiele czynników; przodek ten najprawdopodobniej nie miał mechanizmów obronnych przed namnażaniem się retroelementów [15]. Wobec tego, po nagromadzeniu bardzo dużej liczby intronów w genomie jądrowym, zapewne nastąpiła ich wzmożona utrata - gdyż obecność zbyt wielu wtrąconych elementów mogła okazać się niekorzystna i prowadzić do zmniejszenia przeżywalności organizmu [34].

Przypuszczalnie dzięki zjawisku utraty intronów powstały długie sekwencje kodujące białka oraz cząsteczki które są bezpośrednio zaangażowane $\mathrm{w}$ proces spliclingu [35]. W efekcie tego z intronów grupy II mogły powstać introny spliceosomalne [15]. Uzasadnieniem tego przypuszczenia jest istnienie uderzających podobieństw zarówno w strukturze intronów obydwu typów (zwłaszcza w obrębie złączy), jak i w przebiegu splicingu [24].

\section{MECHANIZMY UTRATY INTRONÓW SPLICEOSOMALNYCH}

Badania mające na celu wyjaśnienie molekularnego podłoża utraty określonych intronów $\mathrm{w}$ poszczególnych liniach ewolucyjnych ciągle trwają. Nie wszystkie z proponowanych wyjaśnień zostały powszechnie zaakceptowane. Dotychczas wskazano trzy podstawowe procesy prowadzące do zmniejszenia liczby wtrąconych sekwencji: (I) utratę intronów za pośrednictwem odwrotnej transkrypcji, (II) na skutek delecji oraz (III) w wyniku naprawy uszkodzeń $\mathrm{w}$ obu niciach DNA (ang. double-strand break repair; DSBR) [1,7].

\section{UTRATA INTRONÓW ZA POŚREDNICTWEM ODWROTNEJ TRANSKRYPCJI}

Hipotetycznie do utraty intronów może dochodzić przy udziale odwrotnej transkryptazy. Pierwszym etapem tego procesu musiałaby być synteza pierwszej nici DNA na matrycy bezintronowej cząsteczki mRNA. Prowadziłoby to do powstania hybrydy RNA-DNA. Wchodząca w jej skład nić RNA ulegałaby częściowej degradacji przez RNazę H. Pozostałości nici RNA mogłyby zostać wykorzystane przez odwrotną transkryptazę (która może być polimerazą DNA zależną od RNA i od DNA) jako starter do syntezy drugiej nici DNA. Ostatnim etapem byłaby rekombinacja powstałego DNA z DNA genomowym zawierającym introny (Ryc. 1a). Wskutek tego mogłoby dojść do utraty jednego lub nawet kilku intronów jednocześnie. Wyniki badań przeprowadzonych na drożdżach S. cerevisiae potwierdzają działanie takiego mechanizmu [37]. W przypadku innych grup eukariontów taki model utraty intronów wydaje się być nieco bardziej kontrowersyjny. Utrata wtrąconych sekwencji za pośrednictwem odwrotnej transkrypcji powinna powodować wzrost częstotliwości jednoczesnej utraty kilku sąsiadujących intronów [38]. Część badań potwierdza tę tendencję, niemniej w większości przypadków introny są tracone pojedynczo w losowych miejscach $[39,40]$.

\section{UTRATA INTRONÓW NA SKUTEK DELECJI}

Utrata intronu przez delecję może nastąpić w następstwie crossing-over między allelami albo wskutek błędu podczas replikacji. Utrata intronu w wyniku rekombinacji jest możliwa w przypadku, gdy w jednym $\mathrm{z}$ dwóch homologicznych chromosomów znajduje się gen bez intronu. W trakcie rekombinacji odcinek DNA niezawierający intronu zastępuje fragment $\mathrm{z}$ intronem [41]. W przypadku delecji powstałej $\mathrm{w}$ wyniku błędu replikacji bardzo często dochodzi do niedokładnego usunięcia intronu (Ryc. 1b). Część nukleotydów intronowych może pozostać $\mathrm{w}$ zmienionej sekwencji lub mogą zostać usunięte dodatkowe nukleotydy z eksonów flankujących intron. Jeżeli delecja nie powoduje zmiany ramki odczytu oraz nie wprowadza znaczących zmian $\mathrm{w}$ sekwencji aminokwasowej, to zmodyfikowana sekwencja bez intronu może stać się funkcjonalna [42,43].

\section{UTRATA INTRONÓW W WYNIKU DZIAŁANIA MECHANIZMÓW NAPRAWY PĘKNIĘĆ DNA}

Przerwanie wiązań fosfodiestrowych w podwójnej helisie może nastąpić $\mathrm{w}$ efekcie działania wolnych rodników tlenu, pod wpływem promieniowania jonizującego albo $\mathrm{w}$ wyniku procesów metabolicznych zachodzących w komórce. Naprawa tych pęknięć jest kluczową kwestią dla przeżycia komórki, dlatego też u organizmów wykształciły się dokładne procesy naprawcze [44]. Mechanizm naprawy dwuniciowych pęknięć DNA może prowadzić do utraty intronów. Przerwanie obu nici DNA sprawia, że rozpada się on na dwa osobne fragmenty, które mogą łatwo degradować. W przypadku opóźnienia reakcji mechanizmów naprawczych dla pęknięcia znajdującego się w obrębie intronu, może on ulec degradacji. Po połączeniu obu fragmentów uszkodzonego DNA dany gen może już nie zawierać intronu (Ryc. 1c).

\section{MECHANIZMY NABYWANIA INTRONÓW SPLICEOSOMALNYCH}

Mechanizmy nabycia intronów są $\mathrm{w}$ dalszym ciągu tematem badań i ożywionych dyskusji [44-46]. Zaproponowano osiem prawdopodobnych mechanizmów prowadzących do powstania intronu $\mathrm{w}$ nowym miejscu $\mathrm{w}$ genomie: (I) transpozycję intronu, (II) insercję transpozonu, (III) tandemową duplikację w genomie, (IV) transfer intronów, (V) nabycie intronów przez naprawę dwuniciowych pęknięć DNA, (VI) insercję intronu grupy II, (VII) konwersję eksonu w intron oraz (VIII) powstawanie intronów spliceosomalnych (konwencjonalnych) $\mathrm{z}$ intronów niekonwencjonalnych. Każdy $\mathrm{z}$ nich należy rozpatrywać $\mathrm{w}$ kontekście bezpośrednich dowodów molekularnych oraz dowodów pośrednich, wynikających $\mathrm{z}$ analiz genomowych $[44,45]$.

\section{NABYWANIE INTRONÓW PRZEZ ICH TRANSPOZYCJĘ}

Proces zyskiwania intronów przez transpozycję (ang. intron transposition) jest wieloetapowy. Najpierw zachodzi transkrypcja, po czym z powstałego pre-mRNA są wycinane introny. Następnie do dojrzałej cząsteczki mRNA, przy sprzyjających ku temu warunkach, włączany jest wycięty wcześniej intron pochodzący $\mathrm{z}$ danego lub innego transkryptu. Tak zmodyfikowany mRNA służy jako matryca do 
syntezy DNA, przeprowadzanej przez odwrotną transkryptazę. Ostatnim etapem jest rekombinacja powstałego DNA z DNA genomowym.

Możliwe są trzy scenariusze nabycia intronów w ten sposób. Pierwszy zakłada, że może dojść do całkowitej lub niemalże całkowitej rekombinacji pomiędzy DNA zawierającym nowy intron, a oryginalnym locus. Do rekombinacji może dojść na pełnej długości genu, w którym występują zarówno eksony jak i inne introny. Skutkiem tego może być jednoczesne nabycie nowego intronu oraz utrata intronów pierwotnie znajdujących się w danym obszarze. Druga możliwość polega na częściowej rekombinacji pomiędzy DNA zawierającym nowy intron, a regionem eksonowym. Takie zdarzenie prowadzi tylko do nabycia intronu (Ryc. 2a). Trzecia ewentualność zakłada wstawienie DNA z nowym intronem w innym locus, a następnie przeniesienie intronu przez częściową bądź kompletną rekombinację do pierwotnego locus [44].

Nabycie intronów przez transpozycję uchodzi za najbardziej prawdopodobny $\mathrm{z}$ ośmiu domniemanych mechanizmów [47]. Przesłanek potwierdzających tę hipotezę dostarczyła analiza blisko spokrewnionych gatunków grzybów z rodzaju Mycosphaerella (Zymoseptoria). Porównanie genomów trzech organizmów ujawniło transpozycję intronów pomiędzy niepowiązanymi ze sobą genami. Niedawno nabyte introny są uderzająco podobne do sekwencji, od których mogły pochodzić. Po przeanalizowaniu sekwencji należących do M. graminicola (Z. tritici), znaleziono 38 rodzin intronów. Każda z nich zawierała introny o prawdopodobnym wspólnym pochodzeniu [46]. Z tych grup wykluczono 16 rodzin obejmujących introny, które zapewne powstały w wyniku całkowitej lub częściowej duplikacji genu posiadającego intron. W pozostałych grupach znajdowały się introny, które prawdopodobnie zostały nabyte przez transpozycję. Odkryto również, że niektóre introny są częściej wstawiane w nowych pozycjach niż inne (określono to na podstawie liczby spokrewnionych intronów $\mathrm{w}$ danej rodzinie), co oznacza, że obecność niektórych motywów wewnątrz sekwencji intronów może promować transpozycję. Dotychczas jeszcze nie scharakteryzowano dokładnie molekularnych mechanizmów transpozycji intronów pomiędzy niespokrewnionymi genami [44].

Intron wstawiany poprzez transpozycję zawiera wszystkie sekwencje niezbędne do jego usunięcia z nowego miejsca, zatem jest w pełni funkcjonalną strukturą w nowym genie [44]. Prowadzone są badania nad czynnikami odpowiedzialnymi za inicjowanie nabywania intronów przez transpozycję oraz okolicznościami, w których ten proces mógłby wystąpić w naturalnych warunkach [48].

Nabycie intronów przez transpozycję udało się wymusić w warunkach laboratoryjnych u $S$. cerevisiae z mutacją helikazy Prp22. Cechą charakterystyczną tego szczepu drożdży jest to, że po zajściu splicingu dojrzałe mRNA pozostają związane ze spliceosomem. Dzięki temu można zaobserwować nieuwolnione struktury mRNA oraz intronu $\mathrm{w}$ formie lassa. W przypadku obniżenia w pożywce stężenia jednowartościowych kationów (uczestniczących w regulowaniu przebiegu transestryfikacji) zaobserwowano zjawisko odwrotnego splicingu (odwrócenie drugiej reakcji transestryfikacji). Dzięki temu większość sekwencji intronowych powróciła do swojego pierwotnego położenia. Niestety tym sposobem nie udało się wstawić intronu w nową pozycję [48].

\section{NABYWANIE INTRONÓW PRZEZ INSERCJĘ TRANSPOZONU}

W zależności od miejsca integracji z genomem, skutki insercji transpozonu (ang. transposon insertion) mogą w

\section{a. utrata intronu w wyniku RT}

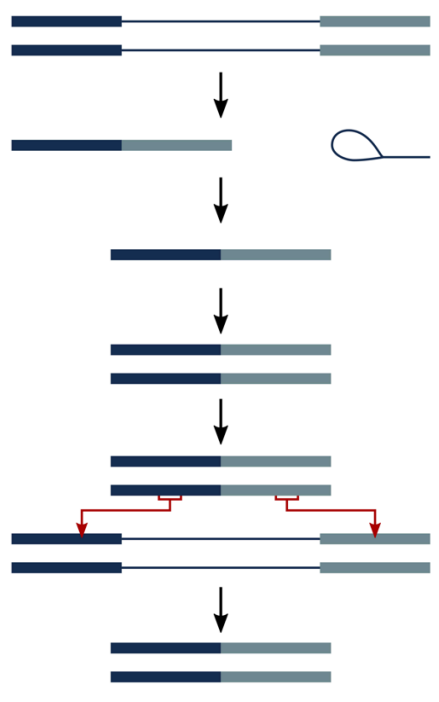

b. delecja intronu

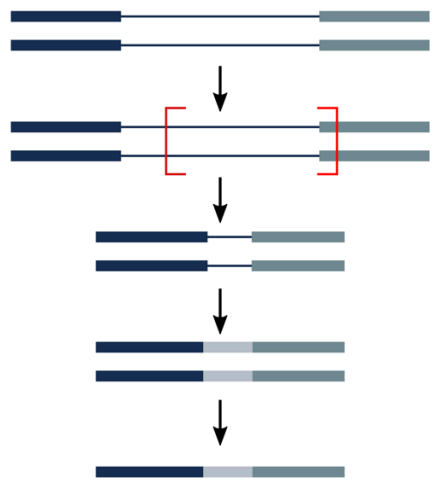

c. naprawa dwuniciowych pęknięć DNA

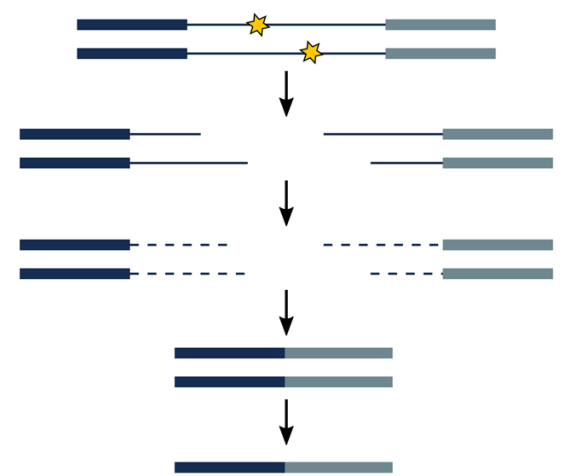

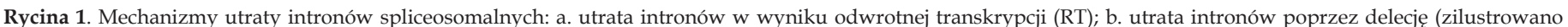

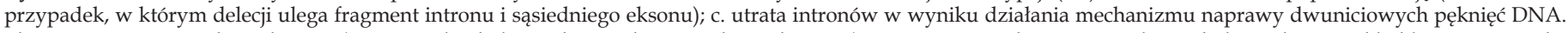

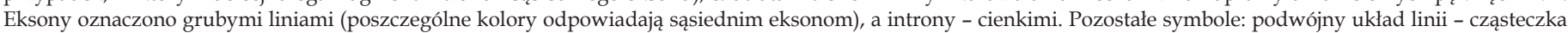

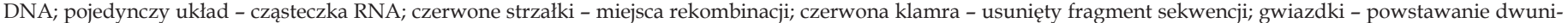
ciowych pęknięć; przerywana linia - fragmenty sekwencji intronu ulegające degradacji. 
a. transpozycja intronu

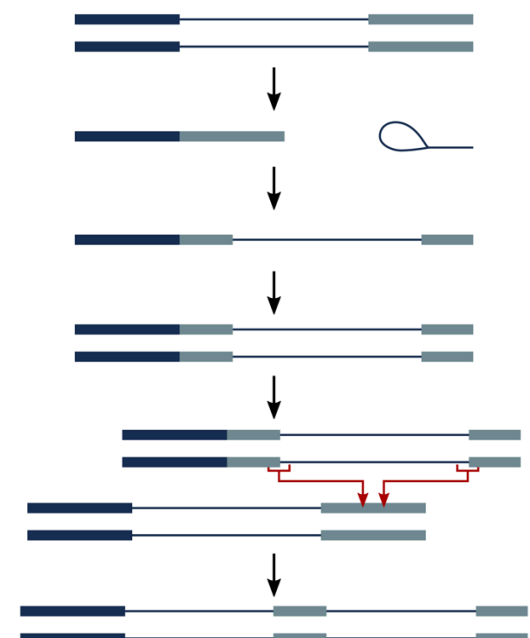

d. transfer intronu

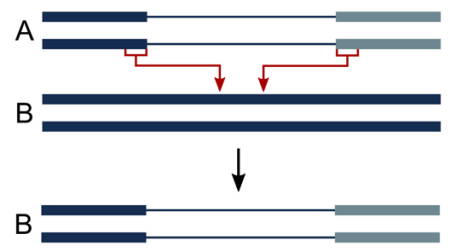

b. insercja transpozonu

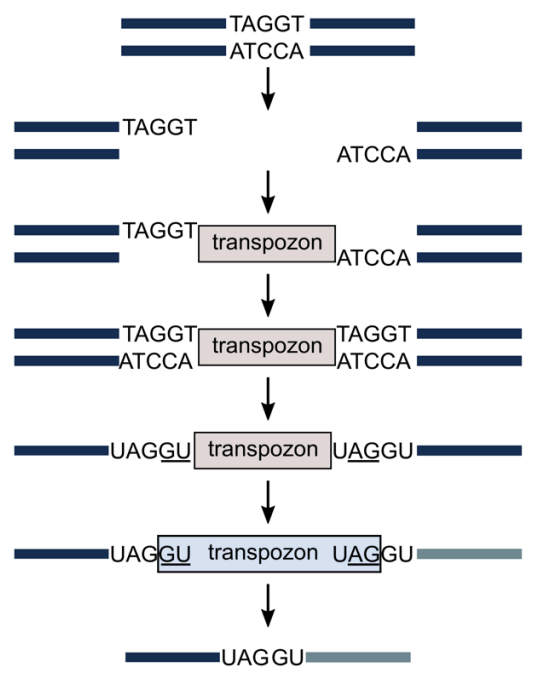

e. naprawa dwuniciowych pęknięć DNA
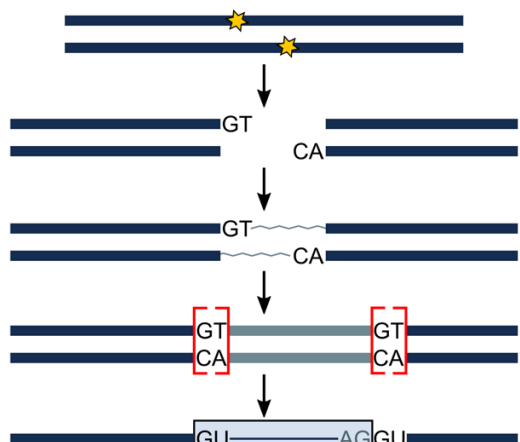

$\underline{\underline{\text { UU }}}$

$\downarrow$

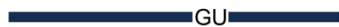

c. tandemowa duplikacja

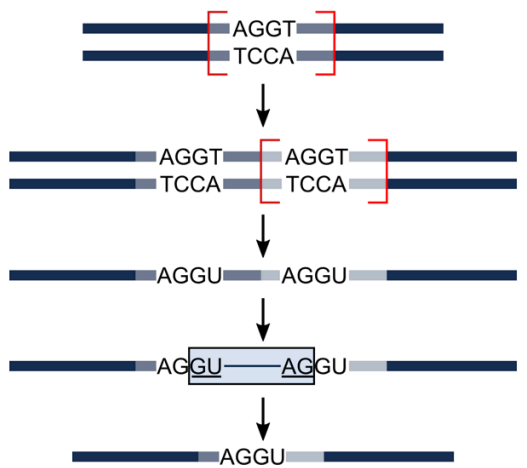

f. insercja intronu grupy II

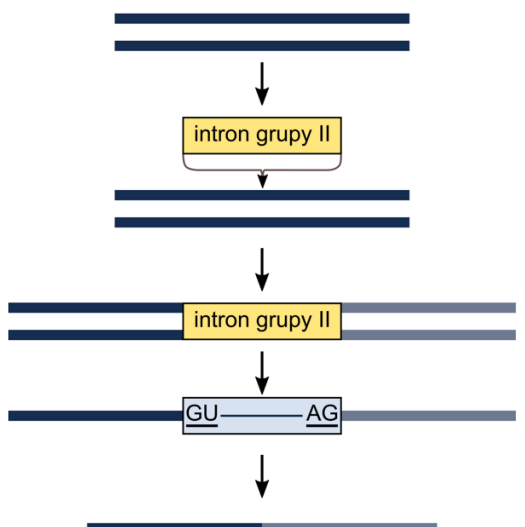

g. konwersja eksonu w intron

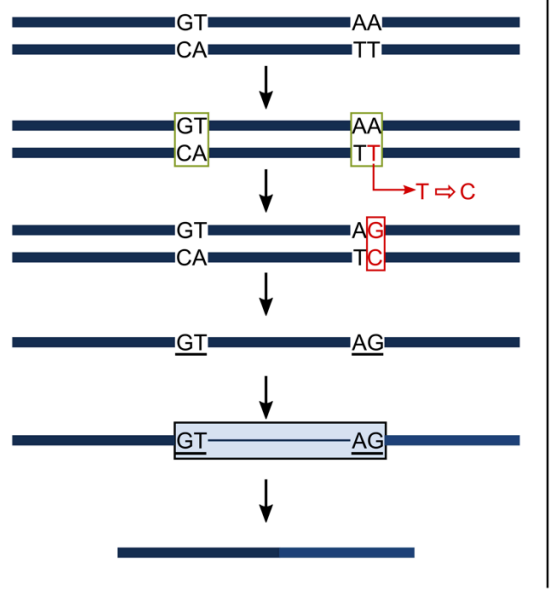

h. powstawanie intronów spliceosomalnych z intronów niekonwencjonalnych
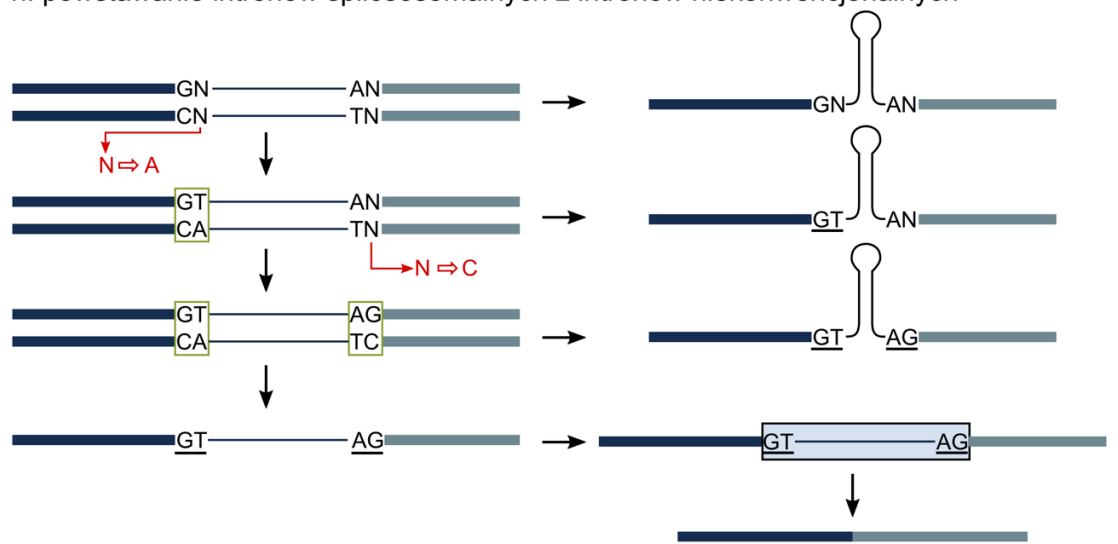

Rycina 2. Mechanizmy nabywania intronów spliceosomalnych: a. transpozycja intronu; b. insercja transpozonu; c. tandemowa duplikacja; d. transfer intronu; e. nabywanie intronu przez naprawę dwuniciowych pęknięć DNA; f. insercja intronu grupy II; g. konwersja eksonu w intron; h. powstawanie intronów spliceosomalnych z intronów niekonwencjonalnych. Eksony oznaczono grubymi liniami (poszczególne kolory odpowiadają sąsiednim eksonom). Introny oznaczono cienkimi liniami. Podkreślono kanoniczne sekwencje złączy intronów spliceosomalnych. Pozostałe symbole: podwójny układ linii - cząsteczka DNA; pojedynczy układ - cząsteczka RNA; czerwone strzałki z klamrą - miejsca rekombinacji; różowy prostokąt - transpozon; błękitny prostokąt - sekwencje rozpoznawane i usuwane przez spliceosom; żółty prostokąt - intron grupy II; czerwone klamry - zduplikowane fragmenty sekwencji; zielona ramka - potencjalne nowe miejsce splicingowe rozpoznawane przez spliceosom; czerwona ramka - mutacja prowadząca do powstania miejsca akceptorowego; pogrubiona strzałka - substytucja nukleotydowa. 
mniejszym lub większym stopniu rzutować na funkcjonowanie organizmu. Wstawienie sekwencji transpozonowych do regionów eksonowych jest powszechnie uważane za szkodliwą zmianę w genomie - najczęściej przyczynia się do inaktywacji genu [49]. Natomiast w przypadku, gdy transpozon zostaje umieszczony w obrębie lepkich końców sekwencji AGGT, określanej jako miejsce protosplicingowe, może dojść do nabycia intronu (Ryc. 2b). Po wniknięciu transpozonu pomiędzy takie końce, polimeraza odbudowuje komplementarne fragmenty nici i $\mathrm{w}$ ten sposób transpozon zostaje włączony do genomu gospodarza [1,44,50]. Po transkrypcji nowo powstała sekwencja pre-mRNA może być rozpoznawana przez spliceosom i w efekcie tego wycinana jako intron [46]. Aby do tego doszło, na końcu 5' (donorowym) nukleotydy powinny utworzyć sekwencję AG|GT (gdzie "|" określa miejsce przyłączenia/odłączenia intronu), natomiast na końcu 3' (akceptorowym) powinno powstać miejsce AG|G. Transpozon wstawiony $\mathrm{w}$ ten sposób nie powoduje zmiany w obrębie sekwencji kodującej [44].

Jeden z najnowszych przypadków nabycia intronów wskutek insercji transpozonów zaobserwowano u zielenicy Micromonas pusilla. Genom u M. pusilla zyskał tysiące niewielkich intronów spliceosomalnych o bardzo podobnych sekwencjach, nazywanych elementami intronowymi (ang. introner elements). Elementy intronowe nie zawierają wewnętrznych ramek odczytu, posiadają za to odwrócone powtórzenia sekwencji na obu końcach (ang. terminal inverted repeats), co wskazuje na to, że są krótkimi nieautonomicznymi transpozonami DNA. Zauważono również, że elementy intronowe $\mathrm{w}$ chromatynie występowały zawsze między nukleosomami. Dalsze analizy dowiodły istnienia podobnych sekwencji także u Aureococcus anophagefferens - glonów zaliczanych do stramenopili, odlegle spokrewnionych z M. pusilla. Dostrzeżono, że w genomach obu organizmów elementy intronowe były oflankowane kilkunukleotydowymi powtórzeniami o charakterystycznej długości (8 bp u A. anophagefferens i 3 bp M. pusilla), powstałymi wskutek duplikacji sekwencji docelowej (ang. target site duplication). Obecność tych powtórzeń sugeruje, że w miejscach insercji elementów intronowych pierwotnie musiało dojść do powstania dwuniciowych pęknięć, generujących lepkie końce. Ubytki wpierw musiały zostać wypełnione przez transpozazę (kodowaną gdzie indziej w genomie). Następnie, za sprawą tego samego enzymu, zostały wstawione elementy intronowe [50].

Niedawno opublikowane wyniki badań nad Fritillaria borealis (niewielkimi zwierzętami morskimi zaliczanymi do otwornic) dowiodły, że genomy tych organizmów zostały masowo skolonizowane przez introny pochodzące od MITEs. Introny zaobserwowane u Fritillaria występują $\mathrm{w}$ wielu kopiach $\mathrm{w}$ pojedynczym genomie, posiadają zbliżone rozmiary i odwrócone powtórzenia nukleotydowe zlokalizowane w pobliżu złączy. Co więcej, są oflankowane krótkimi powtórzeniami, które świadczą o duplikacji w obrębie sekwencji docelowych. Wszystkie te cechy świadczą o ich bliskim pokrewieństwie ewolucyjnym z transpozonami zaliczanymi do MITEs. W dodatku okazuje się, że zdecydowana większość intronów w genomach Fritillaria posiada sekwencje złączy AG-AC/T, zatem odbiegające od konsensusu przyjętego dla intronów spliceosomalnych. Niemniej jednak z badań wynika, że za usuwanie tych sekwencji najprawdopodobniej odpowiada spliceosom. Masowe nabywanie intronów przez insercję transpozonów musiało znacząco destabilizować genomy Fritillaria. Odpowiedzią na to zagrożenie mogła być ewolucja spliceosomu umożliwiająca procesowanie intronów o nietypowych złączach. Zagadnienie to wymaga jednak dalszych badań, podobnie jak molekularne podłoże przekształcenia MITEs $\mathrm{w}$ introny [51].

\section{NABYWANIE INTRONÓW PRZEZ TANDEMOWĄ DUPLIKACJĘ W GENOMIE}

Tandemowa duplikacja intronu w genomie jest określana jako autentyczny i powszechny sposób nabywania intronów. Kiedy dotyczy ona fragmentu DNA zawierającego wewnątrzgenowy motyw AGGT, wówczas powstają blisko siebie dwa silne miejsca splicingowe. Nabycie intronu przez tandemową duplikację może zajść na dwa sposoby. Pierwszy polega na precyzyjnym wstawieniu intronu tak, że ramka odczytu genu pozostaje niezmieniona, a introny są dokładnie usuwane przez spliceosom (Ryc. 2c). Drugi sposób to nieprecyzyjne wstawienie intronu, które sprawi, że sekwencja kodująca ulegnie zmianie. Następuje, gdy wskutek duplikacji fragmentu DNA w obrębie danej sekwencji pojawią się dotychczas nierozpoznawane przez spliceosom miejsca donorowe i akceptorowe. Jeżeli spliceosom zacznie rozpoznawać sekwencje wewnątrz zduplikowanego fragmentu (potencjalne nowe złącza intron/ekson wewnątrz powielonej sekwencji), wówczas w wyniku splicingu nastąpi dodanie nukleotydów do sekwencji kodującej genu (wydłużenie ramki odczytu). Taka duplikacja może również spowodować aktywację miejsc splicingowych zlokalizowanych nie bezpośrednio wewnątrz zduplikowanej sekwencji, a w jej pobliżu, co będzie skutkować usunięciem nukleotydów z sekwencji kodującej (skróceniem ramki odczytu) [44].

Zaobserwowano kilka przypadków nabycia intronów w ten sposób. W genie kodującym polimerazę RNA zależną od RNA (ang. RNA-dependent RNA polymerase; RdRp) u ziemniaka (Solanum tuberosum) zauważono tandemową duplikację fragmentu eksonu, posiadającego sekwencję AGGT. W wyniku tej mutacji powstały miejsca splicingowe GT i AG dla nowego intronu, który jest rozpoznawany i wycinany przez spliceosom. Z badań nad blisko spokrewnionymi przedstawicielami rodzaju Solanum wynika, że wspomniana duplikacja nie występowała u ostatniego wspólnego przodka tych roślin. Dodatkowa sekwencja zawierająca intron pojawiła się dopiero u $S$. tuberosum [52].

\section{NABYWANIE INTRONÓW PRZEZ ICH TRANSFER}

To hipotetyczny sposób zyskiwania intronów, polegający na rekombinacji między dwoma paralogami lub między genem i pseudogenem. W takim przypadku jeden $z$ homologicznych genów nie zawiera intronu, zaś drugi posiada sekwencję intronową (Ryc. 2d). Mechanizm ten nie tłumaczy, jak doszło do wcześniejszego nabycia intronu przez jedną z form. Wyjaśnia natomiast, jak dany intron może rozpowszechniać się w genach o podobnej sekwencji i wspólnym 
pochodzeniu ewolucyjnym. Pośrednie dowody nabycia intronu przez transfer sugerują, że czasami transfer intronu do genu może być nieprecyzyjny. Takie zdarzenie może skutkować inaktywacją docelowej kopii genu.

Prawdopodobieństwo nabycia intronów przez transfer powinno być większe $\mathrm{w}$ genach posiadających paralogi niż w genach pozbawonych swoich odpowiedników. Dlatego też obecność intronów w genach o wspólnym pochodzeniu ewolucyjnym powinna być częstsza. O poprawności tej hipotezy może świadczyć zaobserwowany u większości organizmów trend posiadania większej liczby intronów w genach paralogicznych [44].

Niedawno zbadano rozmieszczenie intronów w genie a-amylazy, który został przeniesiony z Actinobacterium do przodka Agaricomycotina (należącego do Basidomycetes). Z przeprowadzonych analiz wynika, że po utrwaleniu się $\mathrm{w}$ genomie grzyba, gen ten zyskał wiele nowych intronów. Uległ też duplikacjom u kilku gatunków. Następnie, $\mathrm{u}$ różnych przedstawicieli Agaromycotina dochodziło do nabywania oraz utraty intronów. Co ciekawe, po początkowym zwiększeniu liczby intronów, częściej dochodziło do późniejszych strat niż wstawienia intronów w nowych pozycjach. O utratach intronów świadczyły konserwowane sekwencje, które zachowały się wokół dawnych miejsc insercji. W przypadku zachowanych intronów, motywy wewnętrzne, takie jak miejsca donorowe i akceptorowe w większości pozostawały niezmienione. Dzięki transferowi intronów nowy gen zyskał cechy typowe dla genów Basidomycetes: skrócenie eksonów do niewielkich rozmiarów oraz pofragmentowanie sekwencji kodującej w regularny sposób [53].

\section{NABYWANIE INTRONÓW WSKUTEK DZIAŁANIA MECHANIZMÓW NAPRAWY NICI DNA}

Zjawisko to przypomina proces, w którym przerwanie obu nici DNA może skutkować utratą intronu. Istnieją dwa sposoby naprawiania dwuniciowych pęknięć: homologiczna rekombinacja oraz niehomologiczne łączenie konców obu nici (ang. non-homologous end joining; NHEJ). Ten ostatni nie wymaga obecności nieuszkodzonego szablonu, w postaci np. siostrzanej chromatydy. W wyniku NHEJ może nastąpić wstawienie losowych nukleotydów w miejscu przerwania obu nici w sposób prowadzący do powstania sygnału rozpoznawanego przez spliceosom - czyli stworzenia nowego intronu [44] (Ryc. 2e).

U Daphnia nowe, krótkie introny uzyskane przez NHEJ stanowią $43 \%$ ogółu nabytych intronów. Co ciekawe, podczas naprawy za sprawą NHEJ, do DNA jądrowego preferencyjnie jest wprowadzane DNA mitochondrialne. Badania wykazały, że jeden z powstałych w ten sposób intronów jest homologiczny do sekwencji mitochondrialnego $16 S$ rRNA u Daphnia. Jednak dotychczas nie wiadomo, dlaczego mechanizm NHEJ częściej wykorzystuje fragmenty DNA mitochondrialnego [54].

Równie intrygującym aspektem działania NHEJ jest tendencja do pojawiania się krótkich powtórzeń sekwencji w pobliżu miejsc splicingowych. Przypuszcza się, że jest to rezultat uzupełniania lepkich końców po niesymetrycz- nym pęknięciu nici DNA. Wspomniany trend jest zależny od gatunku, typu komórek oraz rodzaju NHEJ w nich zachodzącego, a w niektórych przypadkach nie jest w ogóle obserwowany [44].

\section{NABYWANIE INTRONÓW PRZEZ INSERCJĘ INTRONÓW GRUPY II}

Zwiększenie liczby intronów spliceosomalnych w genomie jądrowym teoretycznie może być też spowodowane nabyciem nowych intronów grupy II, pochodzących z genomów organellarnych [44]. Introny te mogą samodzielnie przemieszczać się w genomach bakteryjnych oraz organellarnych $[15,22]$. Zdaniem badaczy, to $\mathrm{z}$ nich wyewoluowały introny spliceosomalne [22]. Istnieje wiele podobieństw pomiędzy intronami grupy II oraz intronami spliceosomalnymi, takich jak mechanizm wycięcia z pierwotnego transkryptu, forma fizyczna usuniętego intronu, czy zbliżone sekwencje na końcach 5' i 3' [24,36].

Spekuluje się, że powstanie intronów spliceosomalnych mogło być związane z insercją intronów grupy II pochodzących od endosymbionta, który dał początek mitochondriom [44]. Możliwe, że introny grupy II pochodzenia organellarnego w dalszym ciągu mogą pojawiać się w nowych pozycjach genów jądrowych, po czym zostawać skutecznie rozpoznawane przez spliceosom, stając się tym samym intronami spliceosomalnymi (Ryc. 2f).

Obecnie nie są znane przykłady nowo nabytych intronów spliceosomalnych, które powstałyby w ten sposób. Również dane eksperymentalne nie wspierają takiej możliwości. Udowodniono doświadczalnie, że wstawienie intronu grupy II do genu eukariotycznego prawie całkowicie hamuje jego ekspresję. Taki wynik sugeruje, że introny podlegają selektywnej presji - aby utrzymać się w genomie, muszą przejść pewne modyfikacje [55]. Z drugiej strony nie można jednoznacznie wykluczyć możliwości usuwania sekwencji intronów grupy II przez spliceosom.

\section{NABYWANIE INTRONÓW POPRZEZ ZAMIANĘ EKSONU W INTRON}

Konwersja eksonu w intron (ang. intronization) polega na powstawaniu intronów w wyniku mutacji w obrębie sekwencji kodującej. W odróżnieniu od innych mechanizmów, nie wymaga wstawienia nowego odcinka w celu nabycia intronu (Ryc. 2g). Wskutek mutacji w eksonie mogą powstać nowe miejsca akceptorowe oraz donorowe rozpoznawane przez spliceosom [56]. Alternatywnie, mutacja może prowadzić do pojawienia się przedwczesnego kodonu kończącego translację. Jeżeli przed miejscem zmutowanym znajduje się sekwencja potencjalnie rozpoznawana przez spliceosom, może dojść do uaktywnienia tego miejsca splicingowego i usunięcia fragmentu sekwencji zawierającej mutację. Ten słabo zbadany proces jest nazywany uaktywnieniem miejsca splicingowego, związanego z wystąpieniem mutacji nonsensownych (ang. nonsense-associated altered splicing). Przywołany mechanizm zabezpiecza nonsensowny transkrypt przed przedwczesną degradacją. Na skutek kolejnych mutacji w sekwencji może dojść do powstania kolejnych silnych sygnałów splicingowych i coraz dokładniejszego usuwania nowo powstałego intronu [57]. 
Nie ma bezpośrednich dowodów potwierdzających nabywanie intronów tą drogą. Na potencjalną konwersję eksonu w intron mogą natomiast wskazywać pośrednie dowody [44]. Analizowano na przykład gen vulcan u Drosophila melanogaster znajdujący się na chromosomie $2 \mathrm{R}$. Znaleziono w nim nowo powstały intron L, a w nim - miejsca splicingowe odpowiedzialne za alternatywny splicing. Białkowy produkt tego genu jest o 22 aminokwasy krótszy niż jego wcześniej opisana wersja. W celu zbadania pochodzenia intronu L, przeprowadzono analizę filogenetyczną w 36 ortologicznych genach Drosophila. Dzięki temu znaleziono mutacje, które w poszczególnych szczepach doprowadziły do powstania intronu. Znaleziono też takie odmiany Drosophila, u których konwersja eksonu w intron wciąż trwa [58].

\section{POWSTAWANIE INTRONÓW SPLICEOSOMALNYCH Z INTRONÓW NIEKONWENCJONALNYCH}

Geny kodujące białka w genomach jądrowych euglenin zawierają introny dwóch zasadniczych typów: konwencjonalne introny spliceosomalne oraz introny niekonwencjonalne o nieznanym mechanizmie wycinania. Niektórzy badacze wyróżniają jeszcze tak zwane introny „pośrednie”, łączące cechy dwóch poprzednich grup. Posiadają one pewne cechy intronów konwencjonalnych (konserwowane sekwencje złączy) oraz intronów niekonwencjonalnych (zdolność do przyjmowania stabilnej struktury drugorzędowej, zbliżającej do siebie końce intronów) [59].

Teoretycznie, za sprawą mutacji neutralnych, w obrębie intronu niekonwencjonalnego mogłyby powstać dodatkowe sygnały rozpoznawane przez spliceosom. Tym samym, poprzez zyskanie konserwowanych sekwencji złączy GT-AG, intron pierwotnie niekonwencjonalny mógłby stać się intronem pośrednim. Następnie, wskutek kolejnej mutacji, inaktywującej pierwotny sygnał splicingu (rozpoznawany przez mechanizm wycinania odpowiedzialny za usuwanie intronów niekonwencjonalnych), mogłoby dojść do zmiany mechanizmu wycinania, a co za tym idzie - do zmiany typu intronu z niekonwencjonalnego, poprzez intron "pośredni”, $\mathrm{w}$ intron konwencjonalny (spliceosomalny) [12] (Ryc. 2h).

Dotychczas nie dowiedziono możliwości usuwania intronów „pośrednich” za sprawą dwóch różnych mechanizmów. Nie zaobserwowano też przykładów ewidentnych zmian typu intronu. Jednak nie oznacza to, że taka sytuacja jest niemożliwa.

\section{PODSUMOWANIE}

Wśród przedstawionych mechanizmów (trzech dotyczących utraty oraz ośmiu związanych z nabyciem intronów) można wyodrębnić dwie grupy zdarzeń: teoretyczne, za którymi przemawiają dowody pośrednie oraz zdarzenia zaobserwowane $\mathrm{w}$ warunkach laboratoryjnych, których istnienie potwierdzono bezpośrednio.

Utratę intronów w wyniku odwrotnej transkrypcji uważa się za proces hipotetyczny. Model ten nie zyskał powszechnej akceptacji. Opisano go na podstawie badań przeprowadzonych na drożdżach $S$. cerevisiae, natomiast nie sprawdza się on w odniesieniu do innych grup organizmów eukariotycznych. Utrata intronów na skutek delecji została udowodniona $\mathrm{w}$ sposób pośredni. Zaobserwowano utratę intronów przez porównanie blisko spokrewnionych gatunków roślin. W przypadku pomidora (Solanum lycopersicum) i ziemniaka (S. tuberosum), których genomy różnią się o mniej niż 10\%, opisano 17 delecji intronów w genach ortologicznych. Z kolei w wyniku porównania Arabidopsis thaliana oraz jego niedalekiego przodka, Arabidopsis lyrata (których linie oddzieliły się niecałe 10 milionów lat temu), opisano aż 114 delecji intronów [52]. Trzecią przyczyną utraty intronów są działania mechanizmów naprawy pęknięć obu nici DNA w obszarze intronu. Występują na to dowody pośrednie, wynikające z obserwacji degradacji genomów ssaków wskutek pęknięć obu nici DNA.

Nabycie intronów poprzez transpozycję ma dowody pośrednie między innymi w postaci wyników badań blisko spokrewnionych gatunków grzybów z rodzaju Zymoseptoria. W badanym przypadku zaobserwowano transpozycje intronów pomiędzy niepowiązanymi ze sobą genami. W odniesieniu do mechanizmu nabywania intronów wskutek insercji transpozonów również można przytoczyć dowody pośrednie. Genom M. pusilla zyskał tysiące intronów spliceosomalnych $\mathrm{z}$ bardzo podobnymi sekwencjami, nazywanych elementami intronowymi. Za tandemowymi duplikacjami genomowymi przemawiają zarówno pośrednie jak i bezpośrednie dowody. Zaobserwowano je u organizmów, takich jak Arabidopsis, Oryza, Caenorhabditis, Drosophila, Cryptococcus. Nabycie intronów przez transfer zostało udowodnione pośrednio na podstawie przekształcenia genu a-amylazy $\mathrm{z}$ bakteryjnego $\mathrm{w}$ grzybowy $\mathrm{w}$ trakcie transferu z Actinobacterium do przodka Agaricomycotina. W przypadku nabycia intronów wskutek działania mechanizmów naprawy DNA również zgromadzono dowody pośrednie. W genomie Daphnia zaobserwowano preferencyjnie wprowadzane do DNA jądrowego fragmenty DNA mitochondrialnego. Z kolei nabycie intronów przez insercję intronów grupy II nadal pozostaje czysto teoretycznym sposobem powstawania intronów. Introny grupy II podlegają selektywnej presji i aby utrzymać się w genomie, muszą przejść szereg modyfikacji. Konwersja eksonu w intron jest procesem, który również można wyjaśnić przez dowody pośrednie. Dzięki porównaniu sekwencji ortologicznych u Drosophila melanogaster znaleziono intron L. Następnie przeprowadzono analizę filogenetyczną w 36 homologicznych genach u Drosophila. Dzięki temu można było wskazać takie odmiany Drosophila, u których proces zamiany eksonu w intron nadal zachodzi.

Wydaje się, że pierwsze introny spliceosomalne $\mathrm{w}$ genach jądrowych organizmów eukariotycznych pochodziły z jednego źródła (samowycinające się introny grupy II?). Jednakże proces pozyskiwania (a także tracenia) intronów w genomach eukariontów wcale się nie skończył. Obecnie jest za to odpowiedzialny nie jeden, uniwersalny mechanizm, tylko wiele różnych mechanizmów, wywołujących ten sam efekt - uzyskanie niekodującego fragmentu DNA, który następnie może zostać usunięty $\mathrm{z}$ transkryptu $\mathrm{w}$ uniwersalnym procesie splicingu, katalizowanym przez spliceosom.

Nie można wykluczyć, że $\mathrm{w}$ poszczególnych grupach organizmów preferowane są różne mechanizmy nabywa- 
nia intronów. Może to wynikać z charakterystycznych cech struktury genomów czy też uwarunkowań zewnętrznych. Warto przy tym podkreślić, że nowe introny mogą być trwale nabywane $\mathrm{w}$ toku ewolucji, co potwierdza, że nie są „śmieciowym DNA", ale elementami istotnymi dla funkcjonowania genomów.

\section{PIŚMIENNICTWO}

1. Roy SW, Gilbert W (2006) The evolution of spliceosomal introns: patterns, puzzles and progress. Nat Rev Genet. 7: 211-221

2. Le Hir H, Nott A, Moore MJ (2003) How introns influence and enhance eukaryotic gene expression. Trends Biochem Sci 28: 215-220

3. Csuros M, Rogozin IB, Koonin EV (2011) A detailed history of intron-rich eukaryotic ancestors inferred from a global survey of 100 complete genomes. PLoS Comput Biol 9: 1-9

4. Rodríguez-Trelles F, Tarrío R, Ayala FJ (2006) Origins and Evolution of Spliceosomal Introns. Annu Rev Genet 40: 47-76

5. Parenteau J, Maignon L, Berthoumieux M, Catala M, Gagnon V, Abou Elela S (2019) Introns are mediators of cell response to starvation. Nature 565: 612-617

6. Haddrill PR, Waldron FM, Charlesworth B (2008) Elevated levels of expression associated with regions of the Drosophila genome that lack crossing over. Biol Lett 4: 758-761

7. Rogozin IB, Carmel L, Csuros M, Koonin EV (2012) Origin and evolution of spliceosomal introns. Biol Direct 7: 11

8. Woodson SA (2005) Structure and assembly of group I introns. Curr Opin Struct Biol 15: 324-330

9. Martínez-Abarca F, Toro N (2000) Group II introns in the bacterial world. Molecular Microbiol 38: 917-926

10. Christopher A, Hallick RB (1989) Euglena gracilis chloroplast ribosomal protein operon: a new chloroplast gene for ribosomal protein L5 and description of a novel organelle intron category designated group III. Nucleic Acids Res 17: 7591-608

11. Yoshihisa T (2014) Handling tRNA introns, archaeal way and eukaryotic way. Front Genet 5: 1-16

12. Milanowski R, Karnkowska A, Ishikawa T, Zakryś B (2014) Distribution of conventional and nonconventional introns in tubulin ( $\alpha$ and $\beta$ ) genes of euglenids. Mol Biol Evol 31: 584-593

13. Matera AG, Wang Z (2014) A day in the life of the spliceosome. Nat Rev Mol Cell Biol 15: 108-21

14. Will CL, Lührmann R (2011) Spliceosome structure and function. Cold Spring Harb Perspect Biol 3(7): a003707

15. Novikova O, Belfort M (2017) Mobile Group II introns as ancestral eukaryotic element. Trends Genet 33(11): 773-783

16. Hausner G, Hafez M, Edgell DR (2014) Bacterial group I introns: mobile RNA catalysts. Mob DNA 5(1):8

17. Nawrocki EP, Jones TA, Eddy SR (2018) Group I introns are widespread in archaea. Nucleic Acids Res 46(15): 7970-7976

18. Schuster A, Lopez JV, Becking LE, Kelly M, Pomponi SA, Wörheide G, Erpenbeck D, Cárdenas P (2017) Evolution of group I introns in Porifera: new evidence for intron mobility and implications for DNA barcoding. BMC E Biol 17(1): 1-21

19. Bachar D, Guillou L, Christen R (2013) Detection of introns in eukaryotic small subunit ribosomal RNA gene sequences. Dataset Pa Biol $1-12$

20. Hedberg A, Johansen SD (2013) Nuclear group I introns in self-splicing and beyond. Mob DNA 4 (1): 17

21. Saldanha R, Mohr G, Belfort M, Lambowitz AM (1993) Group I and group II introns. FASEB J 7 (1): 15-24

22. Lambowitz AM, Zimmerly S (2011) Group II introns: mobile ribozymes that invade DNA. Cold Spring Harb. Perspect Biol 3(8): a003616

23. Fedorova O, Zingler N (2007) Group II introns: structure, folding and splicing mechanism. Biol Chem 388(7): 665-78
24. Smathers CM, Robart AR (2019) The mechanism of splicing as told by group II introns: ancestors of the spliceosome. Biochim Biophys Acta Gene Regul Mech 11-12: 194390

25. Copertino DW, Hall ET, Van Hook FW, Jenkins KP, Hallick RB (1994) A group III twintron encoding a maturase-like gene excises through lariat intermediates. Nucleic Acids Res 22(6): 1029-1036

26. Zimmerly S, Semper C (2015) Evolution of group II introns. Mob DNA 6: $1-19$

27. Karnkowska A, Bennett MS, Triemer RE (2018) Dynamic evolution of inverted repeats in Euglenophyta plastid genomes. Sci Rep 8: 16071

28. Hopper AK, Nostramo RT (2019) TRNA processing and subcellular trafficking proteins multitask in pathways for other RNAs. Front Genet 10: 96

29. Sugahara J, Yachie N, Arakawa K, Tomita M (2007) In silico screening of archaeal tRNA-encoding genes having multiple introns with bulgehelix-bulge splicing motifs. RNA 13(5): 671-681

30. Trotta CR, Miao F, Arn EA, Stevens SW, Ho CK, Rauhut R, Abelson JN (1997) The yeast tRNA splicing endonuclease: A tetrameric enzyme with two active site subunits homologous to the archaeal tRNA endonucleases. Cell 89(6): 849-858

31. Gawryluk RMR, Del Campo J, Okamoto N, Strassert JFH, Lukeš J, Richards TA, Worden AZ, Santoro AE, Keeling PJ (2016) Morphological identification and single-cell genomics of marine diplonemids. Curr Biol 26: 3053-3059

32. Milanowski R, Gumińska N, Karnkowska A, Ishikawa T, Zakryś B (2016) Intermediate introns in nuclear genes of euglenids-Are they a distinct type? BMC Evol Biol 16: 1-11

33. McWatters DC, Russell AG (2017) Euglena transcript processing. Adv Exp Med Biol 979: 141-158

34. Koonin EV (2006) The origin of introns and their role in eukaryogenesis: a compromise solution to the introns-early versus introns-late debate? Biol Direct 1: 22

35. Irimia M, Roy SW (2014) Origin of spliceosomal introns and alternative splicing. Cold Spring Harb. Perspect Biol 6(6): a016071-a016071

36. Lambowitz AM, Belfort M (2015) Mobile bacterial group II Introns at the crux of eukaryotic evolution. Microbiol Spectr 3(1): MDNA3-00502014

37. Derr LK, Strathern JN (1993) A role for reverse transcripts in gene conversion. Nature 361(6408): 170-173

38. Cohen NE, Shen R, Carmel L (2012) The role of reverse transcriptase in intron gain and loss mechanisms. Mol Biol Evol 29(1): 179-186

39. Sharpton TJ, Neafsey DE, Galagan JE, Taylor JW (2008) Mechanisms of intron gain and loss in Cryptococcus. Genome Biol 9: 1

40. Sverdlov AV, Babenko VN, Rogozin IB, Koonin EV (2004) Preferential loss and gain of introns in 3 ' portions of genes suggests a reverse-transcription mechanism of intron insertion. Gene 338(1): 85-91

41. Ma MY, Che XR, Porceddu A, Niu DK (2015) Evaluation of the mechanisms of intron loss and gain in the social amoebae Dictyostelium. BMC Evol Biol 15(1): 286

42. Ma MY, Lan XR, Niu DK (2016) Intron gain by tandem genomic duplication: A novel case in a potato gene encoding RNA-dependent RNA polymerase. PeerJ 4: e2272

43. Rigau M, Juan D, Valencia A, Rico D (2019) Intronic CNVs and gene expression variation in human populations. PLoS Genet 15(1): e1007902

44. Yenerall P, Zhou L (2012) Identifying the mechanisms of intron gain: progress and trends. Biol Direct 7(1): 29

45. Roy SW, Irimia M (2009) Mystery of intron gain: new data and new models. Trends Genet 25(2): 67-73

46. Wu B, Macielog AI, Hao W (2017) Origin and spread of spliceosomal Introns: insights from the fungal clade Zymoseptoria. Genome Biol E 9(10): 2658-2667

47. Torriani SFF, Stukenbrock EF, Brunner PC, McDonald BA, Croll D (2011) Evidence for extensive recent intron transposition in closely related fungi. Curr Biol 21(23): 2017-2022

48. Tseng CK, Cheng SC (2008) Both catalytic steps of nuclear pre-mRNA splicing are reversible. Science 320(5884): 1782-1784 
49. Ayarpadikannan S, Kim HS (2014) The impact of transposable elements in genome evolution and genetic instability and their implications in various diseases. Genomics Inform 12(3): 98

50. Huff JT, Zilberman D, Roy SW (2016) Mechanism for DNA transposons to generate introns on genomic scales. Nature 538(7626): 533-536

51. Henriet S, Colom Sanmartí B, Sumic S, Chourrout D (2019) Evolution of the U2 spliceosome for processing numerous and highly diverse non-canonical introns in the chordate Fritillaria borealis. Curr Biol 29(19): 3193-3199.e4

52. Ma MY, Zhu T, Li XN, Lan XR, Liu HY, Yang YF, Niu DK (2015) Imprecise intron losses are less frequent than precise intron losses but are not rare in plants. Biol Direct 10(1): 24

53. Da Lage JL, Binder M, Hua-Van A, Janeček Š, Casane D (2013) Gene make-up: rapid and massive intron gains after horizontal transfer of a bacterial a-amylase gene to Basidiomycetes. BMC Evol Biol 13: 40

54. Li W, Tucker AE, Sung W, Thomas WK, Lynch M (2009) Extensive, recent intron gains in Daphnia populations. Science 326(5957): 1260-1262
55. Chalamcharla VR, Curcio MJ, Belfort M (2010) Nuclear expression of a group II intron is consistent with spliceosomal intron ancestry. Genes Dev 24(8): 827-836

56. Irimia M, Roy SW (2008) Evolutionary convergence on highly-conserved 3 ' intron structures in intron-poor eukaryotes and insights into the ancestral eukaryotic genome. PLoS Gen 4(8): e1000148

57. Wang J, Chang YF, Hamilton JI, Wilkinson MF (2002) Nonsense-associated altered splicing: a frame-dependent response distinct from nonsense-mediated decay. Mol Cell 10(4): 951-7

58. Zhan L, Meng Q, Chen R, Yue Y, Jin Y, Bell JB (2015) Origin and evolution of a new retained intron on the vulcan gene in Drosophila melanogaster subgroup species. Genome 57(10): 567-572

59. Canaday J, Tessier LH, Imbault P (2001) Analysis of Euglena gracilis alpha-, beta- and gamma-tubulin genes: introns and pre-mRNA maturation. Mol Genet Genomics 265: 153-160

\section{Mechanisms of spliceosomal introns loss and gain}

\section{Antonina Ignatenko, Natalia Gumińska, Rafał Milanowski ${ }^{\varpi}$}

Department of Molecular Phylogenetics and Evolution, Institute of Botany, Faculty of Biology, Biological and Chemical Research Center, University of Warsaw, 101 Żwirki i Wigury Str., Warsaw, Poland

$\square_{\text {corresponding author: milan@biol.uw.edu.pl }}$

Keywords: introns, spliceosomal introns, intron loss, intron gain

\section{ABSTRACT}

Introns are non-coding sequences within the genes. They seemed to be just "junk" DNA, although currently are considered as important genetic elements influencing the genome functions, as they increase the diversity of transcriptome and proteome, perform regulatory activities in the cell, affect gene expression, mRNA processing, degradation and translation. Based on the mechanism of their excision, introns were classified into three main categories: spliceosomal, self-splicing and tRNA introns. Spliceosomal introns are unique for eukaryotic organisms. Sequence analyses of orthologous genes in different groups of eukaryotes revealed many cases of intron gains and losses due to the multiple mechanisms. Some of these events took place in the distant past, while others happened relatively recently. It is believed that these processes can act as one of the forces driving the evolution of eukaryotic genes. 